\title{
PROFIL PERESEPAN OBAT PEYAKIT DIARE PADA PASIEN RAWAT INAP ANAK DI RSU Dr. KANUJOSO DJATIWIBOWO BALIKPAPAN
}

\section{Profile Of The Diarrhea Prescribing Of Children Inpatients At Hospital Dr. Kanudjoso Djatiwibowo Balikpapan}

\author{
Yullia Sukawaty ${ }^{1}$, Rusdiati Helmidanora ${ }^{2}$, Fitri Handayani ${ }^{3}$ \\ ${ }^{1,2,3}$ Dosen Akademi Farmasi Samarinda \\ sukawatyyullia@gmail.com
}

\begin{abstract}
ABSTRAK
Diare merupakan salah satu penyebab utama kematian terutama pada anak-anak. Sekitar $10 \%$ kasus diare pada anak berusia dibawah lima tahun (balita) di seluruh dunia merupakan diare berdarah atau disentri.

Tujuan penelitian ini adalah untuk mengetahui profil peresepan obat penyakit diare pada pasien rawat inap anak di Rumah Sakit Umum Dr. Kanudjoso Djatiwibowo Balikpapan periode OktoberDesember tahun 2015.

Penelitian ini dilakukan dengan metode retrosfektif non eksperimental dengan pengambilan sampel secara purposive sampling dan dianalisa secara deskriptif menggunakan microsoft excel.

Profil peresepan obat penyakit diare pada pasien rawat inap anak di RSU Dr. Kanujoso Djatiwibowo Balikpapan meliputi penggunaan antibiotik tunggal terbanyak ceftriaxone $24 \%$, antibiotik kombinasi yang terbanyak digunakan yaitu ampicillin kombinasi dengan chloramphenicol $12 \%$, terapi rehidrasi yang banyak digunakan yaitu ringer laktat $38 \%$, terapi suplemen yang banyak digunakan yaitu zink $90 \%$.

Peresepan obat untuk penyakit diare pasien rawat inap anak di Rumah Sakit Umum Dr. Kanudjoso Djatiwibowo Balikapapan telah sesuai dengan protap tata laksana pengobatan diare Departemen Kesehatan RI (Depkes RI 2011) lima langkah tuntaskan diare.
\end{abstract}

Kata kunci : diare, obat, peresepan

\begin{abstract}
Diarrhea is one of the leading causes of death especially in children. Approximately $10 \%$ of cases of diarrhea in children under five years old (toddlers) worldwide are bloody diarrhea or dysentery. The purpose of this study was to determine profile of the diarrhea prescribing of children inpatients at hospital Dr. Kanudjoso Djatiwibowo Balikpapan period October to December 2015.

This research was conducted by non experimental retrospectively method with purposive sampling and analyzed descriptively using microsoft excel.

Profile of the diarrhea prescribing of children inpatients at hospital Dr. Kanudjoso Djatiwibowo Balikpapan encompasses the use of the single most antibiotic ceftriaxone $24 \%$, the most commonly used combination antibiotic, ampicillin combination with chloramphenicol $12 \%$, rehydration therapy widely used lactate ringer $38 \%$, supplement therapy widely used zinc $90 \%$. Prescribing medication for diarrheal disease of inpatients at hospital Dr. Kanudjoso Djatiwibowo Balikapapan has been in accordance with the procedure of diarrhea treatment of Ministry of Health RI (MOH RI 2011) five steps to solve diarrhea.
\end{abstract}

Keywords: diarrhea, medication, prescribing 


\section{PENDAHULUAN}

Angka kejadian diare pada anak di dunia mencapai 1 miliar kasus tiap tahun, dengan korban meninggal sekitar 4 juta jiwa. Angka kematian balita di negara Indonesia akibat diare ini sekitar 2,8 juta jiwa setiap tahun. Penyakit diare disebabkan oleh banyak faktor diantaranya kondisi lingkungan, perilaku orang tua dan pemenuhan nutrisi. Kebanyakan dari masyarakat selama ini hanya memahami bahwa diare terjadi dikarenakan makanan yang sudah tercemar. Diare merupakan salah satu penyebab utama kematian terutama pada anak-anak. Sekitar 10\% kasus diare pada anak berusia dibawah lima tahun (balita) di seluruh dunia merupakan diare berdarah atau disentri (Hardi, dkk, 2012).

Penyakit diare masih menjadi masalah global dengan derajat kesakitan dan kematian yang tinggi diberbagai negara terutama di negara berkembang. Indonesia merupakan salah satu negara berkembang dengan angka kejadian penyakit diare yang tinggi karena tingginya morbiditas dan mortalitas (Magdarina, 2010).

Hasil Survei Kesehatan Rumah Tangga (SKRT) di Indonesia, diare merupakan penyebab kematian nomor 2 pada balita dan nomor 3 bagi bayi serta nomor 5 bagi semua umur. Setiap anak di Indonesia mengalami kasus diare sebanyak 1,6-2 kali per tahun. Pada tahun 2004, angka kematian akibat diare 23/100.000 penduduk dan pada balita 75/100.000 balita. Selama tahun 2006 sebanyak 41 kabupaten di 16 provinsi melaporkan Kejadian Luar Biasa (KLB) diare di wilayahnya. Jumlah kasus diare yang dilaporkan sebanyak 10.980 dan 277 diantaranya menyebabkan kematian (Depkes RI, 2009).

Secara klinis diare didefinisikan sebagai bertambahnya defekasi (buang air besar) lebih dari biasanya/lebih dari tiga kali sehari, disertai dengan perubahan konsisten tinja (menjadi cair) dengan atau tanpa darah. Secara klinik dibedakan tiga macam sindrom diare yaitu diare cair akut, disentri, dan diare persisten.

Menurut Dewi, dkk., (2011) penggunaan obat anti diare pada pasien anak di Rumah Sakit Umum Daerah Banyumas telah sesuai dengan standar pelayanan medik menurut Ikatan Dokter Indonesia. Berdasarkan penelitian Numlil, dkk (2012) penggunaan obat diare pada pasien anak di Rumah Sakit Umum Budi Asih telah sesuai dengan toolkit yang digunakan. Penggunaan antibiotik banyak digunakan untuk infeksi yang disebabkan oleh bakteri. Ditemukan 40-62\% antibiotik digunakan secara tidak tepat kepada pasien yang sebenarnya tidak membutuhkan antibiotik. Penggunaan antibiotik yang cukup sering menyebabkan resistensi bakteri (Depkes RI, 2011 ).

Penyakit diare di Balikpapan masih termasuk 10 penyakit terbesar, bahkan menduduki urutan ke lima. Dilihat dari profil penyakit di Rumah Sakit Umum Dr. Kanudjoso Djatiwibowo periode Oktober tahun 2015.

Berdasarkan latar belakang di atas, maka peneliti tertarik untuk melakukan penelitian tentang “ profil peresepan obat penyakit diare pada pasien rawat inap anak di rumah sakit umum Dr. Kanudjoso Djatiwibowo Balikpapan Oktober-Desember 2015. Penelitian dilakukan di Rumah Sakit Umum Dr. Kanudjoso Djatiwibowo Balikpapan periode Oktober-Desember tahun 2015, untuk mendapatkan data terbaru dari Rumah Sakit Umum Dr. Kanudjoso Djatiwibowo Balikpapan yang merupakan rujukan tertinggi di daerah Balikpapan.

\section{METODE PENELITIAN}

\section{Alat dan Bahan}

Alat yang di gunakan berupa formulir pengambilan data yang dibuat dalam bentuk tabel yang meliputi : tanggal masuk pasien, nama pasien, umur, jenis kelamin, diagnosa penyakit, obat yang diberikan.

Bahan berupa data pasien anak rawat inap Flamboyan usia 0-12 tahun dengan diagnosa A09 (diare cair akut) yang diperoleh dari bagian rekam medis di RSU Dr. Kanujoso Djatiwibowo Balikpapan periode Oktober - Desember 2015.

\section{Metode Penelitian}

\section{a. Pengumpulan Data}

Data yang diperoleh adalah data sekunder berupa status pasien anak penderita diare yang menjalani rawat inap di Flamboyan yang di kumpulkan dari bagian rekam medis di RSU Dr. Kanujoso Djatiwibowo periode Oktober - Desember 2015. Data dikumpulkan, dilakukan pencatatan dalam 
formulir pengambilan data berdasarkan tanggal masuk rumah sakit, nama pasien, jenis kelamin, diagnosa penyakit, obat yang digunakan.

\section{b. Pengolahan Data}

Data yang telah dicatat dalam pengambilan data, ditabulasi dan diklasifikasikan berdasarkan umur, jenis kelamin, dan obat-obatan yang digunakan.

\section{c. Pembahasan}

Pembahasan dibuat berdasarkan hasil penelitian dari pengolahan data.

\section{d. Kesimpulan}

Pengambilan kesimpulan didasarkan pada hasil penelitian dan pembahasan, serta disesuaikan dengan tujuan penelitian yang telah dibuat dan saran ditujukan kepada pihak rumah sakit.

\section{e. Analisis Data}

Data yang diperoleh akan dikelompokkan atau ditabulasi berdasarkan umur, jenis kelamin, dan obat yang digunakan dan dianalisis secara deskriptif menggunakan Microsoft Excel.

\section{HASIL PENELITIAN DAN PEMBAHASAN \\ Demografi Pasien Diare Anak}

Pada penelitian ini, peneliti mengambil data dari rekam medis pasien anak yang menderita diare di ruang rawat inap Flamboyan Rumah Sakit Umum Dr. Kanudjoso Djatiwibowo Balikpapan pada Oktober-Desember 2015 diperoleh data sebanyak 34 pasien dengan rincian 16 pasien dengan diagnosa diare cair akut dan 18 pasien dengan penyakit lain yaitu infeksi saluran kemih, apendisitis, abses colli, demam berdarah, pneumonia, epilepsi (abdominal pain), ileus, paralitik dan sepsis. Gambaran pasien diare anak berdasarkan diagnosa pasien dapat dilihat pada tabel 1. Diare adalah penyakit infeksi yang tidak menutup kemungkinan memiliki penyakit penyerta.

Tabel 1. Data persentase berdasarkan diagnosa

\begin{tabular}{llcc}
\hline & \multicolumn{1}{c}{ Uraian } & Jumlah & \% \\
\hline Diagnosa Utama & Diare & 16 & 47 \\
\hline Diagnosa Lain & Infeksi Saluran Kemih & 1 & 3 \\
\cline { 2 - 4 } & Apendisitis & 1 & 3 \\
\cline { 2 - 4 } & Abses Colli & 1 & 3 \\
\cline { 2 - 4 } & Demam Berdarah & 4 & 12 \\
\cline { 2 - 4 } & Pneumonia & 3 & 9 \\
\cline { 2 - 4 } & Epilepsi & 1 & 3 \\
\cline { 2 - 4 } & Bronkopneumonia & 2 & 3 \\
\cline { 2 - 4 } & Stomatitis Akut & 1 & 3 \\
\cline { 2 - 4 } & Nyeri Perut (Abdominal Pain) & 1 & 3 \\
\cline { 2 - 4 } & Ileus paralitik & 2 & $\mathbf{1 0 0}$ \\
\cline { 2 - 4 } & Sepsis & $\mathbf{3 4}$ & 3 \\
\hline Jumlah & & & \\
\hline
\end{tabular}

Pasien anak yang menderita penyakit diare di ruang rawat inap Flamboyan Rumah Sakit Umum Dr.Kanujoso Djatiwibowo dari 34 pasien terdiri anak laki-laki $55 \%$ dan anak perempuan $44 \%$. Gambaran pasien diare anak berdasarkan jenis kelamin pasien dapat dilihat pada tabel 2 . Hal ini berarti bahwa penyakit diare lebih banyak diderita oleh anak laki-laki dibanding dengan anak perempuan. Secara khusus belum ada penelitian atau teori yang menunjukkan adanya hubungan jenis kelamin dengan penyakit diare. Baik anak laki-laki maupun perempuan mempunyai peluang yang sama besar untuk menderita sakit diare, selama penyebab timbulnya sakit diare tetap merata di semua wilayah.

Tabel 2. Jumlah Penderita Berdasarkan Jenis Kelamin

\begin{tabular}{ccc}
\hline Jenis Kelamin & Jumlah & Persentase (\%) \\
\hline Laki - laki & 19 Orang & 56 \\
\hline Perempuan & 15 Orang & 44 \\
\hline Total & $\mathbf{3 4}$ & $\mathbf{1 0 0}$
\end{tabular}


Anak yang menderita diare yang dirawat di ruang Flamboyan Rumah Sakit Dr. Kanujoso Djatiwibowo meliputi berbagai usia. Gambaran pasien diare anak berdasarkan usia pasien seperti yang terlihat pada tabel 3 .

Tabel 3. Jumlah pasien berdasarkan usia

\begin{tabular}{ccc}
\hline Usia Pasien & Jumlah Pasien & Persentase (\%) \\
\hline$<1$ tahun & 11 Orang & 32 \\
\hline $1-5$ tahun & 18 Orang & 53 \\
\hline$>5$ tahun & 5 Orang & 15 \\
\hline Jumlah & $\mathbf{3 4}$ & $\mathbf{1 0 0}$ \\
\hline
\end{tabular}

\section{Karekteristik Obat}

\section{a. Terapi Pengobatan Pasien Diare Pada Anak}

Pada tabel 4 dapat diketahui antibiotika yang digunakan selama terapi, terlihat bahwa dari 34 pasien diare, tercatat 17 pasien (50\%) menggunakan terapi pengobatan dengan antibiotika dan 17 pasien $(50 \%)$ tidak mendapatkan terapi pengobatan dengan antibiotik.

Tabel 4. Data persentase berdasarkan terapi pengobatan

\begin{tabular}{ccc}
\hline Terapi Pengobatan & Jumlah & Presentase $(\%)$ \\
\hline Dengan Terapi Antibiotik & 7 & 50 \\
\hline Tanpa Terapi Antibiotik & 7 & 50 \\
\hline Total & 34 & 100 \\
\hline
\end{tabular}

\section{b. Variasi Pemberian Antibiotika pada Pasien Diare Anak}

Berdasarkan data penggunaan antibiotika untuk pasien diare anak umur 0-12 tahun di ruang rawat inap Flamboyan Rumah Sakit Umum Dr. Kanudjoso Djatiwibowo periode Oktober-Desember tahun 2015 didapatkan variasi pemberian antibiotika terbagi dalam bentuk tunggal dan kombinasi.

Tabel 5. Data persentase berdasarkan variasi pemberian antibiotik

\begin{tabular}{ccc}
\hline Terapi Pengobatan & Jumlah & Persentase \% \\
\hline Tunggal & 21 & 84 \\
\hline Kombinasi & 4 & 16 \\
\hline Jumlah & 25 & 100 \\
\hline
\end{tabular}

\section{c. Jenis Antibiotik yang Digunakan}

Antibiotika yang digunakan selama terapi adalah ceftriaxone $24 \%$, cefotaxime $20 \%$, cotrimoxazole $12 \%$, cefixim $8 \%$, metronidazole $8 \%$, chloramphenicol $4 \%$, erythromicyn $4 \%$, amoxicillin 4\%, ampicillin kombinasi dengan chloramphenicol $12 \%$, cefotaxime kombinasi dengan metronidazole 4\%. Penggunaan antibiotika yang terdapat dalam tabel 6 diberikan dalam bentuk secara tunggal dan kombinasi.

Tabel 6. Data persentase antibiotik yang digunakan

\begin{tabular}{ccc}
\hline Nama Obat (antibiotik) & Jumlah & Presentase (\%) \\
\hline Ceftriaxone & 6 & 24 \\
\hline Cefotaxime & 5 & 20 \\
\hline Cotrimoxazole & 3 & 12 \\
\hline Cefixime & 2 & 8 \\
\hline Metronidazole & 2 & 8 \\
\hline Chloramphenicol & 1 & 4 \\
\hline Erythromicyn & 1 & 4 \\
\hline Amoxicillin & 1 & 4 \\
\hline Ampicillin + Chloramphenicol & 3 & 12 \\
\hline Cefotaxime + Metronidazole & 1 & 4 \\
\hline Jumlah & 25 & 100 \\
\hline
\end{tabular}

Penggunaan antibiotik pada kasus diare sangat tergantung pada faktor etiologinya. Pada keadaan tertentu berdasarkan pada pola potomekanisme yang dihadapi dan anamnesis, relatif sudah cukup 
untuk mendeteksi faktor penyebabnya (etiologi) sehingga pemilihan obat telah dapat diperkirakan sebagaimana diketahui tidak semua kasus-kasus diare dapat diobati dengan antibiotik seperti diare yang disebabkan oleh infeksi rotavirus dan diare yang disebabkan oleh faktor non infeksi. Menurut Tjay dan Raharja (2007), hanya pada diare yang disebabkan bakteri yang perlu dilakukan terapi dengan antibiotik. Pilihan utama adalah amoxicillin, cotrimoxazole, dan senyawa fluorkinolon.

Cotrimoxazole lebih banyak digunakan dalam terapi pengobatan diare karena cotrimoxazole merupakan kombinasi antara sulfametoxazol dan trimetoprim dengan perbandingan 5:1 $(400+80$ mg) yang berefek sinergi. Kedua komponen kombinasinya bersifat bakterisida terhadap bakteri yang sama dan banyak digunakan untuk berbagai penyakit infeksi, salah satunya infeksi saluran erna karena lebih jarang menimbulkan resistensi. Pada umumnya kombinasi dari sulfametoxazole dan trimetoprim memperkuat khasiatnya (potensiasi) serta menurunkan resiko resistensi dengan kuat (Tjay dan Raharja, 2007).

Amoxicillin efektif terhadap penyakit infeksi saluran kemih (gonore tidak terkomplikasi, uretritis, sistitis, pielonefritis), infeksi saluran pernapasan kronik dan akut (pneumonia, faringitis bukan karena gonore, bronchitis, laringitis), infeksi saluran cerna (disentri basiler) serta infeksi lainnya seperti septikemia, endokarditis. Pemberian terapi pengobatan dengan Amoxicillin dalam kasus diare diberikan karena golongan ini lebih sering digunakan untuk penyakit infeksi dan lebih sering diresepkan dan juga mempunyai aktivitas anti bakteri yang baik. Dosis amoxicillin yang diberikan pada anak dengan berat badan kurang dari $20 \mathrm{~kg}$ adalah $20-40 \mathrm{mg} / \mathrm{kg}$ berat badan sehari dalam dosis terbagi tiap 8 jam.

Pasien anak dengan diagnosa utama diare mendapat terapi cotrimoxazole sebesar $12 \%$ dan amoxicillin sebesar 4\%. Pada Pasien anak dengan diagnosa penyakit lain mendapat terapi cefixim $8 \%$, metronidazole $8 \%$, cefotaxime $20 \%$, ceftriaxone $24 \%$, chloramphenicol $4 \%$. Terapi antibiotik tunggal yang diberikan kepada pasien diare dengan penyakit lain terbesar yaitu ceftriaxone. Ceftriaxone merupakan antibiotik beta-laktam dari golongan sefalosforin yang umumnya bersifat bakterisid, dan sebagian besar efektif terhadap gram positif dan negatif, antibiotik beta-laktam mengganggu sintesis dinding sel bakteri.

Terapi antibiotik kombinasi pada pasien diare dengan penyakit lain yaitu cefotaxime dan metronidazole $4 \%$, yang terbanyak yaitu ampicillin dan chloramphenikol $12 \%$, ampicillin merupakan antibiotik beta-laktam berspektrum luas yang efektif terhadap Gram-positif dan negatif, mengganggu sistesis dinding sel bakteri. Chloramphenikol adalah antibiotik berspektrum luas, menghambat bakteri Gram-positif dan negatif aerob dan anaerob, Klamidia, Ricketsia, dan Mikoplasma. chloramphenikol mencegah sistesis protein dengan berikatan subunit ribosom 50S (Depkes RI, 2011c).

Antibiotik kombinasi adalah pemberian antibiotik lebih dari satu jenis untuk mengatasi infeksi. Tujuan pemberian antibiotik kombinasi yaitu, untuk meningkatkan aktivitas antibiotik pada infeksi spesifik (efek sinergis), untuk menghambat dan mengurangi resiko timbulnya bakteri resisten.

Penggunaan antibiotika baik tunggal maupun kombinasi merupakan penggobatan yang tidak rasional dan tidak dianjurkan. Efek samping penggunaan antibiotik yang tidak rasional mengakibatkan interaksi obat yang mungkin terjadi serta perlu diperhatikan mengenai resiko terjadinya resistensi.

\section{d. Terapi Cairan Rehidrasi yang Digunakan}

Hasil penilitian pada tabel 7 menunjukkan bahwa pengobatan diare anak diberikan terapi cairan pengganti (rehidrasi) paling banyak pemberian cairan infus Ringer Laktat 38\%, D5 1/4 NS $32 \%$, D5 $1 / 2$ NS 27\%, Ka-en 3B 3\%.

Tabel 7. Data persentase cairan rehidrasi yang digunakan

\begin{tabular}{ccc}
\hline Cairan Rehidrasi & Jumlah & Persentase \% \\
\hline Ringer Laktat & 13 & 38 \\
\hline
\end{tabular}




\begin{tabular}{ccc}
\hline D5 $1 / 4$ NS & 11 & 32 \\
\hline D5 1/2 NS & 9 & 27 \\
\hline Ka-en 3B & 1 & 3 \\
\hline Jumlah & $\mathbf{3 4}$ & $\mathbf{1 0 0}$ \\
\hline
\end{tabular}

Berdasarkan data yang didapat, diketahui penggunaan ringer laktat dalam penelitian ini yang terbanyak. Ringer laktat merupakan cairan garam fisiologis steril yang kandungan asam basanya menyerupai cairan plasma darah. Ringer laktatmengandung garam $\mathrm{NaCl}(6 \mathrm{~g}), \mathrm{KCl}(0,3 \mathrm{~g}), \mathrm{CaCl} 2$ $(0,2 \mathrm{~g})$, dan $\mathrm{Na}$ laktat $(3,1 \mathrm{~g})$ dalam setiap 1 liter cairan. Cairan ini berfungsi untuk mengembalikan osmolaritas dan elektrolit tubuh secara cepat melalui rehidrasi intravena. Larutan ringer laktat akan di metabolisme oleh hati menjadi bikarbonat yang berguna untuk memperbaiki keadaan seperti asidosis metabolik. Ringer laktat biasa diberikan pada penderita diare yang mengalami dehidrasi yang berat atau yang berpotensi menjadi berat sehingga memerlukan rehidrasi intravena secara cepat. Selain itu ringer laktat tidak mengandung glukosa, sehingga sering kali dapat ditambahkan glukosa yang berguna untuk mencegah terjadinya ketosis (Rudi, 2006).

Pemberian terapi cairan pengganti merupakan pengobatan diare yang utama pada penyakit diare yaitu dengan menggunakan terapi cairan atau elektrolit, seperti yang tertera pada tata laksana pengobatan diare Departemen Kesehatan RI (Depkes RI, 2011).

\section{e. Terapi dengan Suplemen}

Suplemen yang digunakan selama terapi adalah zink yaitu sebanyak $90 \%$ dan probiotik sebanyak 10\%. Data penelitian dapat dilihat pada tabel 7. Zink adalah sebuah mikronutrisi yang bisa ditemukan di semua jaringan tubuh dan penting bagi pertumbuhan sel, deferiansiasi sel dan sintesis DNA juga penting untuk menjaga sistem daya tahan tubuh yang sehat (Fountaine, 2008).

Tabel 8. Data persentase terapi dengan suplemen

\begin{tabular}{ccc}
\hline Suplemen & Jumlah & Persentase \% \\
\hline Zink & 26 & 90 \\
\hline Probiotik & 3 & 10 \\
\hline Jumlah & 29 & 100 \\
\hline
\end{tabular}

Menurut WHO (World Health Organization) dan UNICEF pada tahun 2004 merekomendasikan penggunaan zink sebagai bagian dari tata laksana pengobatan diare. Hingga akhirnya setelah dilakukan penelitian di berbagai negara, zink dimasukkan dalam daftar obat esensial oleh WHO. Dalam tata laksana pengobatan diare akut, zink mampu mengurangi durasi episode diare hingga $25 \%$. Beberapa penelitian menunjukkan pemberian zink mampu menurunkan volume dan frekuensi tinja rata-rata sebesar 30\%. Zink juga menurunkan durasi dan keparahan diare persisten. Bila diberikan secara rutin pada anak-anak baik jangka panjang maupun jangka pendek, zink mampu menunjukkan efektivitas dalam mencegah diare akut maupun persisten dan mampu memberikan manfaat menurunkan prevalensi diare yang disebabkan disentri dan shigellosis.Setelah dilakukan penelitian tentang pengobatan zink pada diare berpuluh-puluh tahun lamanya, akhirnya zink direkomendasikan oleh WHO dan UNICEF. Rekomendasi yang diberikan adalah zink diberikan selama 10-14 hari pada pasien anak diare di bawah usia 5 tahun, bayi usia di bawah 6 bulan dapat diberikan zink $10 \mathrm{mg}$ setiap hari, dan anak usia 6 bulan hingga 5 tahun diberikan dengan dosis 20 mg setiap hari.

Hasil penelitian pada pasien rawat inap anak dengan diare akut di ruang Flamboyan Rumah Sakit Umum Dr. Kanujoso Djatiwibowo yang menggunakan probiotik yaitu sebanyak $10 \%$.

Penggunaan probiotik efektif sebagai pencegahan dan pengobatan diare. Probiotik adalah bakteri hidup baik yang membantu nutrisi di saluran gastrointestinal dan memberikan pertahanan untuk melawan bakteri patogen Fungsi probiotik adalah sebagai pertahanan mukosa, fungsi proteksi dan pertahanan imunitas saluran cerna seperti misalnya lapisan epitel, lapisan mukus, peristaltik, dan deskuamasi epitel, serta sekresi imunoglobulin A (IgA), sangat berpengaruh terhadap perlekatan kuman patogen dan juga untuk modulasi sistem imun lokal dan sistemik. Probiotik adalah oligosakarida yang memiliki efek yang tidak biasa di dalam usus. Mereka mengubah komposisi, atau keseimbangan, dari mikrobiota, baik dalam lumen dan pada permukaan mukosa. Probiotik juga 
bertindak sebagai karbon dan sumber energi bagi bakteri yang tumbuh di usus besar, di mana mereka difermentasi dan merupakan sumber energi untuk usus dan jaringan tubuh lainnya. Untuk tujuan peraturan, definisi 'probiotik' perlu diklarifikasi, khususnya yang berkaitan dengan konsep yang bukan tentang saluran pencernaan dan parameter yang merupakan modifikasi selektif dari mikrobiota usus (Agus Fathul, 2014).

\section{KESIMPULAN}

Profil peresepan obat penyakit diare pada pasien rawat inap anak di RSU Dr. Kanujoso Djatiwibowo Balikpapan meliputi penggunaan antibiotik tunggal terbanyak ceftriaxone $24 \%$, antibiotik kombinasi yang terbanyak digunakan yaitu ampicillin kombinasi dengan chloramphenicol $12 \%$, terapi rehidrasi yang banyak digunakan yaitu ringer laktat $38 \%$, terapi suplemen yang banyak digunakan yaitu zink $90 \%$.

Peresepan obat untuk penyakit diare pasien rawat inap anak di Rumah Sakit Umum Dr. Kanudjoso Djatiwibowo Balikpapan telah sesuai dengan protap tata laksana pengobatan diare Departemen Kesehatan RI (Depkes RI 2011) lima langkah tuntaskan diare.

\section{KEPUSTAKAAN}

Agus Fathul M.F., Ade Yonata. 2016. Penggunaan Probiotik Sebagai Terapi Diare. Vol. 2(5). Lampung : Fakultas Kedokteran Universitas Lampung

Departemen Kesehatan RI. 2009. Buku Pedoman Pengendalian Penyakit Diare. Departemen Kesehatan Republik Indonesia : Jakarta

Departemen Kesehatan RI. 2011. Kejadian Diare Di Indonesia. Departemen Kesehatan Republik Indonesia : Jakarta

Departemen Kesehatan RI. 2011. Buku Saku Petugas Kesehatan Lima Langkah Tuntaskan Diare. Jakarta : Direktorat Jenderal Pengendalian Penyakit Dan Penyehatan Lingkungan.288-390.

Departemen Kesehatan RI. 2011. Keputusan Menkes RI 2406 /MENKES /PER /XII/2011 tentang pedoman umum penggunaan antibiotik. Departemen Kesehatan Republik Indonesia : Jakarta

Dewi St, Anjar Mk, Indri H. 2011. Evaluasi Penggunaan Obat Antidiare Pada Pasien Anak Di Instalasi Rawat Inap Rsud Banyumas Tahun 2011. Pharmacy 6(1):1693-3591

Fountaine, O. 2008. Bukti Keamanan Dan Kemanjuran Suplementasi Zink Pada Penanganan Diare. Departemen Kesehatan Dan Perkembangan Anak Dan Remaja. WHO. Surabaya

Hardi, A. R., Masni, Rahma. 2012. Faktor- Faktor Yang Mempengaruhi Kejadian Diare Pada Batita Di Wilayah Kerja Puskesmas Baranglompo Kecamatan Ujung Tanah Tahun 2011. Fakultas Kesehatan Masyarakat, Universitas Hasanudin, Makassar

Magdarina. 2010. Morbiditas Dan Mortalitas Diare Pada Balita Di Indonesia Tahun 2000 - 2007. Kementrian Kesehatan RI. Jakarta

Numlil Kr, Betti G, Apriyanti W. 2012. Evaluasi Penggunaan Obat Diare Terhadap Kesesuaian Dosis Dan Pada Pasien Anak Rawat Inap Di Rsud Budi Asih Jakarta. Pharmasains Vol. 1(5) : Jakarta

Tan Hoan Tjay, Kirana Raharja. 2007. Obat-Obat Penting. Edisi 6. Gramedia : Jakarta. Hal 296

Rudi. M.M. 2006. Pengaruh Pemberian Cairan Ringer laktat di bandingkan $\mathrm{NaCl} \mathrm{0,9 \%} \mathrm{Terhadap}$ Keseimbangan Asam-Basa Pada Pasien Sectio Caesaria dengan Anestesi Regional, Tesis, Magister Biomedis, Program Pendidikkan Dokter Spesialis Anestesiologi Universitas Diponegoro, Semarang 